\author{
Agata A. Kluczek
}

(Katowice)

\title{
AENEAS ANCHISIADES I PII FRATRES. KILKA UWAG O KSZTAŁTOWANIU SIĘ WIZERUNKU ENEASZA W MENNICTWIE RZYMSKIM
}

\begin{abstract}
The article discusses certain aspects of representations of Aeneas in Roman coinage, focusing in particular on the declining period of the Republic and Augustus' principate. At the time, Aeneas; father, Anchises, would be depicted on the coins as the sole companion of the former. Although later the figure of the parent carried on a shoulder served as an attribute denoting the Trojan hero depicted on the reverses, the early minted representations of Aeneas were not as unambiguous in that respect. This was due to the fact that portrayals of Aeneas did resemble the manner in which the Catanian Brothers were represented, with both serving potentially as allegories of pietas.
\end{abstract}

\section{Key words}

Aeneas, Catanian Brothers, Pii Fratres, Roman coins, numismatic iconography 
W rozpowszechnionym $\mathrm{w}$ starożytności wizerunku Eneasza istotny był stosunek trojańskiego bohatera do jego ojca, Anchizesa. Akcentowano ich pokrewieństwo i relację, nazywając Eneasza: Aeneas Anchisiades (Verg., Aen. $8.521)^{1}$. Natomiast $w$ dziełach sztuki, zarówno tych oficjalnych, jak i prywatnych, a także w mennictwie rzymskim przedstawiano Eneasza, który niesie Anchizesa. W ten sposób przecież można było dookreślić przymioty trojańskiego uchodźcy, a nawet zdefiniować tożsamość pokazanej postaci. Warunkiem było, co oczywiste, odwołanie się w tych artystycznych realizacjach do szerzej funkcjonującej tradycji przekazów o Eneaszu. Dla czytelności ich przesłania ważne było zwłaszcza zużytkowanie powtarzających się cech portretu bohatera jako ugruntowanych, rozpoznawalnych, mimo że niekiedy czerpanych z różnych źródeł. To musiało prowadzić do tworzenia konkretnych modeli prezentowania Eneasza w sztuce antycznej.

Identyfikacyjny walor szczegółu w ikonografii rewersowej, czyli Anchizesa niesionego przez Eneasza, słusznie wskazuje Alexandra Dardenay przy okazji analizy wyobrażeń medalionów rzymskich, które pochodzą z epoki Antoninów $^{2}$. Powstały one wtedy, gdy w mennictwie, zwłaszcza prowincjonalnym, pewną popularność już zdobył obraz przedstawiający tzw. grupę Eneasza, złożoną z kroczącego Eneasza obarczonego ciężarem Anchizesa i prowadzącego za rękę syna, Askaniusza (Julusa) (por. il. 1)³. Inaczej zaaranżowano

${ }^{1}$ Eneasz jako Anchisiades także: Sil. Ital., Pun. 13.71; Verg., Aen. 5.407, 6.125-126, 322, 348; 10.250, 822; Tetr. Aen. 16 i 43.

2 A. Dardenay, Images des Fondateurs. D’Enée à Romulus, Bordeaux 2012, s. 60-61, 65. Podobną wartość ma postać Askaniusza. Sam Eneasz bowiem może być mylony np. z Romulusem, zob. wyobrażenie na bazie z Falerii Novi, dziś w katedrze w Civita Castellana, por. F. Canciani, Aineias, [w:] L. Kahil (red.), Lexicon iconographicum mythologiae classicae I 1, Zürich-München 1981 (= LIMC), 177; J.D. Evans, The Art of Persuasion, Political Propaganda from Aeneas to Brutus, Ann Arbor 1992, s. 49-50; A. Dardenay, Les mythes fondateurs de Rome. Images et politique dans l'Occident romain, Paris 2010, s. 94-95; eadem, Images, LT7.

${ }^{3} \mathrm{~W}$ takim kształcie w latach 20. I w. p.n.e. stanęła rzeźba na Forum Augusta w Rzymie, por. W. Fuchs, Die Bildgeschichte des Flucht des Aeneas, [w:] W. Haase (red.), Aufstieg und Niedergang der römischen Welt. Geschichte und Kultur Roms im Spiegel der neueren Forschung, Berlin-New York 1973, I, 4, s. 627-629. Posąg znany jest z opisu Ov., Fast. 5.563-665: „Hinc uidet Aenean oneratum pondère caro/et tot Iuleae nobilitatis auos;/hinc uidet Iliaden umeris ducis arma ferentem”, tłum. E. Wesołowska: „Stąd widzi Eneasza objuczonego drogim/brzemieniem i szlachetnych dziadów julijskiego/rodu. Stamtąd zaś widzi, jak Romulus wlecze zbroję zwyciężonego wodza”. Ustalono (por. J. Gagé, Romulus-Augustus, Mélanges de l'École française de Rome 47, 1930, s. 140-144), że zabytek ten stanowił wzorzec dla rzeźby na Gmachu Eumachii w Pompejach, znana jest inskrypcja z bazy: CIL X 809; por. F. Canciani, Aineias, 147, a następnie dla malowidła (dziś zatarte, kopia w Museo della Civiltà Romana) na fullonica Fabiusa Ululitremulusa w Pompejach (IX 13,5); por. F. Canciani, Aineias, 98; W. Fuchs, Die Bildgeschichte, s. 629; G.K. Galinsky, Aeneas, Sicily, and Rome, Princeton 1969, s. 30 nn.; P. Aichholzer, Darstellungen römischer Sagen, Wien 1983, kat. 2; A. Dardenay, Images, s. 167-168 i E72, T28. 
rewersy owych medalionów z II w. (por. il. 2) 4 $^{4}$ Sylwetkę bohatera z ojcem na ramieniu wkomponowano $\mathrm{w}$ scenerię, którą po pierwsze symbolicznie nawiązano do wieszczby o kresie tułaczki, co zwiastowało natknięcie się przez Trojan na maciorę z prosiętami, a po drugie alegoryzowano związek Eneasza z przyszłym Rzymem, ukrytym w obrazie murów miejskich i innych budowli. W wyobrażeniu czyniącym aluzje do wydarzeń na ziemi italskiej oraz do przyszłości rzymskiej postać Anchizesa może wydawać się zbędna ${ }^{5}$, jednak to jej obecność pozwala rozpoznać w drugiej postaci Eneasza.

Przedstawianie Eneasza niosącego na ramieniu swego rodzica miało odleglejszą historię w mennictwie rzymskim. Grupę z tak rozwiniętym motywem Eneasza tworzą monety $\mathrm{z}$ następującymi napisami i ikonografią:

- denarii (mennica w Afryce), 47-46 r. p.n.e., Aw. głowa Wenus, Rw. CAESAR, postać męska krocząca $\mathrm{w}$ lewo, $\mathrm{z}$ palladium $\mathrm{w}$ prawicy, niosąca inną na lewym ramieniu (por. il. 3)

- aurei (Rzym) z 42 r. p.n.e., Aw. C CAESAR IIIVIR R P C, głowa Oktawiana, Rw. L REGVLVS IIIIVIR A P F, postać męska widoczna w profilu, krocząca w prawo, niosąca inną na lewym ramieniu (por. il. 4$)^{7}$,

\footnotetext{
${ }^{4}$ Medaliony Hadriana (134-138 r.), zob. Monnaies Romaines Antiques (collection H.C. Levis), Genève 1925, 526; F. Canciani, Aineias, 143; M. Krumme, Römische Sagen der antiken Münzprägung, Marburg 1995, 56/1, oraz medaliony Antonina Piusa, zob. F. Gnecchi, I medaglioni romani, descritti ed illustrati, 2, Milano 1912, Ant. P., s. 22, 115; F. Canciani, Aineias, s. 144; M. Krumme, Römische Sagen, 57/1 (139 r.).

${ }^{5} \mathrm{~W}$ tradycji reprezentowanej np. przez Wergiliusza Anchizes zmarł na Sycylii, zob. Verg., Aen. 3.707-710. Jednak w Dion. Hal., 1.64.5; Serv., Aen. 1.267 (z powołaniem na dzieło Katona) czytamy, że Anchizes zakończył życie po przybyciu do Lacjum, a przed wojną z Rutulami i Mezencjuszem.

${ }^{6}$ Podaję chronologię za: M.H. Crawford, Roman Republican Coinage, Cambridge 1974 (= RRC), 458/1, mennica w Afryce. Zob. też E.A. Sydenham, The Coinage of the Roman Republic, London 1952 (= CRR), s. 168, 1013 (48 r. p.n.e.); H.A. Grueber, Coins of the Roman Republic in the British Museum, London 1910 (= BMCRR), East, s. 469, 31-35 (48 r. p.n.e.); F. Canciani, Aineias, 128; P. Aichholzer, Darstellungen römischer Sagen, 36; M. Krumme, Römische Sagen, s. 94, 98-100, 21/1; B. Woytek, Arma et Nummi. Forschungen zur römischen Finanzgeschichte und Münzprägung der Jahre 49 bis 42 v. Chr., Wien 2003, s. 218-229 (48-47 r. p.n.e., mennica w Azji Mn.); A. Dardenay, Images, E7.

${ }^{7}$ Podaję chronologię za RRC, 494/3a-b. Zob. też CRR, 1104-1104a (42 r. p.n.e.); BMCRR 1, 4257-4258 (ok. 39 r. p.n.e.); E. Babelon, Description historique et chronologique des monnaies de la République romaine vulgairement appelées monnaies consulaires, 2, Paris 1886, Livineia 5 (43-43 r. p.n.e.); W. Fuchs, Die Bildgeschichte, s. 626-627; F. Canciani, Aineias, 129; M. Krumme, Römische Sagen, s. 101-102 i 23/1; A. Dardenay, Images, E3. Zob. hybrydy, 19 r. p.n.e.: Aw. TVRPILIANVS IIIVIR, głowa Liber; Rw. Eneasz z Anchizesem, A Catalogue of the Roman Coins in the British Museum. Coins of the Roman Empire in the British Museum, H. Mattingly (red.), London 1965-1976 (= BMCRE), 1, s. 5*; M. Krumme, Römische Sagen, 26/1; A. Dardenay, Images, E4.
} 
- brązy (Segesta) z lat 27-21 p.n.e., Aw. ЕГЕ $\Sigma$ TAI $\Omega$ N, głowa Augusta, Rw. postać męska krocząca w lewo, z palladion w prawicy, niosąca inną na lewym ramieniu, po prawej stronie orzeł (por. il. 5) ${ }^{8}$. Wcześniej w Segeście były emitowane monety, które na awersach przedstawiały popiersie Segesty, natomiast na rewersach obok napisu $\Sigma \mathrm{E} \Gamma \mathrm{E} \Sigma \mathrm{TAI} \Omega \mathrm{N}$ miały obraz kroczącej na wprost postaci męskiej, niosącej inną na ramieniu (por. il. 6) , $^{9}$

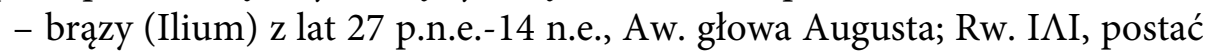
męska na wprost, niosąca inną na lewym ramieniu (por. il. 7) ${ }^{10}$.

Wyobrażenia zawężone do dwóch postaci - Eneasza i Anchizesa - były więc rzadkie. $\mathrm{W}$ mennictwie rzymskim charakterystyczne były one zasadniczo we wczesnym okresie posługiwania się motywem Eneasza, czyli w końcowych latach Republiki i pierwszych latach Cesarstwa ${ }^{11}$. Należy więc dodać,

${ }^{8}$ R.S. Poole (red.), A Catalogue of the Greek Coins in the British Museum, London 1873-1927 (= BMCG), Sicily, Segesta, s. 137, 65, 66; W. Fuchs, Die Bildgeschichte, s. 626; F. Canciani, Aineias, 130; A. Burnett, M. Amandry, P.P. Ripollès (red.), Roman Provincial Coinage, 1, London-Paris 1992 (= RPC), 652; R. Calciati, Corpus Nummorum Siculorum: la monetazione di bronzo, Milano 1983-1987 (= CNS), 1, Segesta, s. 305, 61; M. Krumme, Römische Sagen, s. 98 i 164/1; A. Dardenay, Images, E8; por. G. Guzzetta, La monetazione in Sicilia in „età romana”, [w:] C. Miccichè, S. Modeo, L. Santagati (red.), La Sicilia romana tra Repubblica e Alto Impero, Caltanissetta 2007, s. 191-192 i przyp. 75; S. Mani Hurter, Die Didrachmenprägung von Segesta mit einem Abhang der Hybriden, Teilstücke und Tetradrachmen sowie mit einem Überblick über die Bronzeprägung, Bern 2008, s. 49.

${ }^{9}$ BMCG Sicily, Segesta, s. 137, 59-61; CNS 1, Segesta, s. 304, 54, 56-57. Chronologia emisji: po 241 r. p.n.e., co zaproponował B.V. Head (Historia Nummorum. A Manual of Greek Numismatics, Oxford 1887, s. 146), za nim np.: A. Alföldi, Die trojanischen Urahnen der Römer, Basel 1957, s. 29; G.K. Galinsky, Aeneas, s. 173; F. Canciani, Aineias, 93; P. Aichholzer, Darstellungen römischer Sagen, 35; M. Krumme, Römische Sagen, s. 98 i 155/1; A. Dardenay, Images, E1 (ok. 241 r. p.n.e., błędne odwołanie do BMCRR zamiast BMCG). Kolejne propozycje: M. Caltabiano, Gli eroi omerici nella tipologia monetale antica, Rivista Italiana di Numismatica e Scienze Affini (= RIN) 90, 1988, s. 28: od końca III w. p.n.e.; ogólniej: BMCG Sicily, Segesta, s. 137: „Period of Decline, late”; CNS 1, Segesta, s. 304: „periodo romano”, oraz E.M. Zarrow, Sicily and the Coinage of Octavian and Sextus Pompey: Aeneas or the Catanean Brothers?, Numismatic Chronicle 163, 2003, s. 132-133: po 264 r. p.n.e.; Th.S. Duncan, The Aeneas Legend on Coins, The Classical Journal 44, 1948, s. 22 (po 146 r. p.n.e.); W. Fuchs, Die Bildgeschichte, s. 625-626: poł. I w. p.n.e.

${ }^{10}$ BMCG Troas, Ilium, s. 60, 28; H. von Fritze, Die Münzen von Ilion, [w:] W. Dörpfeld (red.), Troja und Ilion: Ergebnisse der Ausgrabungen in den vorhistorischen und historischen Schichten von Ilion 1870-1894, 2, Athen 1902, 41; RPC, 2306; F. Canciani, Aineias, 131. Związki Trojan i Segesty zob. np. Thuc. 6.2; Cic., Verr. 2.4.72; Strab. 6.254; 2.272; Dion. Hal. 1.52.4; Diod. 23.5; Zon. 8.9 .

${ }^{11}$ Należy też wskazać restytucję denarów Cezara (RRC 458/1) w serii nummi restituti wyemitowanej za rządów Trajana na przełomie 112 i 113 r., zob. BMCRE 3, Tr., s. 141, 31; F. Canciani, Aineias, 134; P. Aichholzer, Darstellungen römischer Sagen, 41; M. Krumme, Römische Sagen, s. 104-105 i 48/8; H. Komnick, Die Restitutionsmünzen der frühen Kaiserzeit. Aspekte der Kaiserlegitimation, Berlin-New York 2001, 38.0; B. Woytek, Die Reichsprägung des Kaisers Traianus (98-117), Wien 2010, 836; A. Dardenay, Images, E9. 
że przynajmniej część tych przedstawień powstała jeszcze przed wprzęgnięciem mitu o Eneaszu czy to w księgę pierwszą dzieła Liwiusza, czy w epopeję pióra Wergiliusza. Przedstawienia te zatem pozostawały pod wpływem aktualnych wcześniej, opartych też na tradycji greckiej, opowieści o Eneaszu, toteż oddają cechy postaci trojańskiego bohatera uformowanej już w tych wczesnych źródłach.

Na rewersach wskazanych monet powtarza się obraz dwóch sylwetek: niosącego i niesionego. Centralną postacią wyobrażenia pozostaje ów portans, czyli Eneasz. Z kolei niesiony, czyli Anchizes, chociaż sam może trzymać pewne akcesoria, staje się atrybutem tego pierwszego, definiującym jego cechy. Obie postacie wyabstrahowano $\mathrm{z}$ tła, nie wskazano również ich tożsamości w napisach monetarnych, identyfikują je tylko poza i gesty. Te nie pozostawały charakterystyczne wyłącznie dla postaci Eneasza i Anchizesa - przeciwnie - były one szerzej używane i mogły określać również ukazywanych w wyobrażeniach monetarnych innych bohaterów. Wszelako tych łączyła z Eneaszem więź ideologiczna utkana z konkretnych wartości i okoliczności.

Pewne podobieństwo rozwiązania ikonograficznego rewersów wykazują denary Cezara (RRC 458/1) i brązy z Segesty (RPC 1, 652). Wyraża się ono w układzie sylwetek bohatera i jego ojca, ale też w dodatkowych wyróżnikach, w jakie ich wyposażono. Eneasz na lewym ramieniu niesie swego rodzica. Anchizes oburącz trzyma na swych kolanach cista sacra, detal ten jest widoczny na denarach, ale nie można przesądzić, że pominięto go na brązach. Ponadto Eneasz w prawicy dzierży paladium. Kiedy wyemitowano chronologicznie pierwsze z tych monet, RRC 458/1, już funkcjonowało przekonanie, któremu w 54 r. p.n.e. wyraz dał Cyceron, że paladium należy do pignora imperii (Cic., Scaur. 48; por. Serv., Aen. 7.188). Było więc związane z ideą trwałości i wieczności imperium rzymskiego, a także powodzenia samego Rzymu (por. Ov., Fast. 6.427-428). W tradycji literackiej paladium jest mocno związane z Eneaszem, który miał je wynieść z Troi (Dion. Hal., 1.69.2; por. 2.66.5) lub na ziemi italskiej otrzymać je od Diomedesa (Cass. Hem. ap. Solin., 2.14). Sam motyw paladium jednak późno wprowadzono do sztuki rzymskiej, a w ikonografii monetarnej - niezmiernie rzadko - umieszczono je w ręku Eneasza. Przedstawienie zaś na denarach RRC 458/1 jest rozwiązaniem zgoła nowatorskim ${ }^{12}$. Cista czy pyxis $\mathrm{w}$ wyobrażeniu numizmatów to

12 Por. R. Pera, L'imperatore ed il divino: il simbolismo del Palladio, [w:] M. Caccamo Caltabiano, D. Castrizio, M. Puglisi (red.), La tradizione iconica come fonte storica: il ruolo della numismatica negli studi di iconografia, Reggio Calabria 2004, s. 75. Jako ciekawostkę ikonograficzną można odnotować układ na intaglio, I w. p.n.e.: nie Eneasz, a Anchizes, niesiony na ramie- 
zapewne inwencja rzymska, bowiem sacra sporadycznie były obecne w tradycji greckiej ${ }^{13}$, natomiast w świecie rzymskim umieszczane w ręku Anchizesa wystąpiły w wielu dziełach sztuki ${ }^{14}$. Eneasz, niosąc ojca, staje się więc zbawcą nie tylko dla niego. Ponieważ pośrednio unosi owe świętości, właśnie mu przypisuje się również ich uratowanie i przeniesienie do Lacjum (por. np. Verg., Aen. 2.717; Ov., Fast. 4.37-38; Ov., Met. 13.624-627).

Przerywnik między tymi dwiema emisjami, w których przedstawiono Eneasza z palladium oraz Anchizesa z cista, stanowią - pod względem ikonografii rewersowej - aureusy RRC 494/3. Choć zachowano na nich podstawowy temat Eneasza niosącego ojca, to jednak inne jest - w profilu - ułożenie ich sylwetek. Anchizes odwraca głowę, jak gdyby odglądając się wstecz, ponadto nie ma tu paladium. Mincerz, L. Livineius Regulus, nie wykorzystał więc modelu wprowadzonego na denarach Cezara. Natomiast rewersy monet tego quattuorvira można przyrównać do znacznie odleglejszego czasowo wzorca, jaki tworzy obraz wykorzystany na denarach u schyłku II w. p.n.e. przez triumvira M. Herenniusa - Aw.: PIETAS, głowa Pietas, Rw.: M HERENNI, postać męska kroczy w prawo, trzymając na lewym ramieniu rodzica (por.

niu syna, trzyma paladium, w grupie znalazł się też Askaniusz prowadzony za rękę przez swego ojca, Médailles et Antiques de la Bibl. nat. de France, de Clercq 3131; zob. [online]. Bibliographie nationale française [dostęp: 2017-04-20]. Dostępny w Internecie: <http://medaillesetantiques.bnf.fr/ ws/catalogue/app/collection/record/ark:/12148/c33gb1rmlb>.

${ }^{13}$ Wyjątkowo pokazano je na intaglio etruskim (V w. p.n.e.) - Bibl. Nat., Coll. de Luynes 276 Eneasz jako przybywający bohater-fundator: w przyklęku, z ojcem na grzbiecie, z tarczą i włócznią, Anchizes natomiast z cista zawierającą sacra uniesione z Troi. Por. A. Alföldi, Die trojanischen Urahnen, s. 15-16; W. Fuchs, Die Bildgeschichte, s. 617; G.K. Galinsky, Aeneas, s. 60; S. Woodford, M. Loudon, Two Trojan Themes: The Iconography of Ajax Carrying the Body of Achilles and of Aeneas Carrying Anchises in Black Figure Vase Painting, American Journal of Archaeology 84, 1980, s. 25-26; F. Canciani, Aineias, 95; N.M. Horsfall, The Aeneas Legend from Homer to Virgil, [w:] J.N. Bremmer, N.M. Horsfall (red.), Roman Myth and Mythography, London 1987, s. 18; A. Dardenay, Les mythes, s. 45, 50; eadem, Images, E22. Z kolei na czerwonofigurowej amforze z Vulci, 470-460 r. p.n.e. - Monaco, Antikesamml, 3186 - Eneasz, Anchizes, Askaniusz i Kreuza niosąca doliolum z sacra. Por. G.K. Galinsky, Aeneas, s. 60; S. Woodford, M. Loudon, Two Trojan Themes, s. 32, przyp. 56; F. Canciani, Aineias, 94. Contra: N. Horsfall, The Iconography of Aeneas' Flight: a Pratical Detail, Antike Kunst 22, 2, 1979, s. 104-105. Niegdýs - R. Texier, A propos de deux représentations archaïques de la fuite d'Énée, Revue Archéologique 14, 1939, s. 16-18 - dopatrywano się cista również w ikonografii monet z Aineia (por. niżej), ale bazowano na egzemplarzu mocno uszkodzonym w tym konkretnym miejscu. O braku większego zainteresowania motywem sacra u greckich autorów i artystów por. A. Dubourdieu, Les origines et le développement du culte des Pénates à Rome, Rome 1989, s. 198-204, 217.

${ }^{14}$ Reprezentatywne, chociaż niewyczerpujące listy zabytków, jest zestawienie F. Cancianiego, Aineias, 98 (malowidło), 114 (fragment sarkofagu), 112 (tabliczka iliacka), 113, 117 (fragmenty ołtarzy), 102-111 (gemmy), 115 (nagrobek), 116, 149-151, 153, 154 (reliefy), 118 (terakota), 119 (wazy), 120-126 (lampki). Zob. też A. Dardenay, Images, katalog, s. 215-237. 
il. 8) ${ }^{15}$. Monety Livineiusa Regulusa i Herenniusa cechuje spore podobieństwo, chociaż różna jest ich stylistyka, a postać główną uchwycono z nieco innej perspektywy ${ }^{16}$.

Wspólnym mianownikiem pięciu wskazanych emisji jest ich zasadniczy wątek ikonograficzny: krocząca postać niosąca inną na ramieniu. Czy jednak dotyczą one wszystkie tego samego tematu - motywu Eneasza? Tożsamości postaci pokazanych $\mathrm{w}$ wyobrażeniach rewersowych nie wskazują napisy. Niemniej co się tyczy emisji Cezara ${ }^{17}$ oraz tych związanych z osobą Oktawiana, a potem Augusta zazwyczaj scenę na ich rewersach interpretuje się jako przedstawienie Eneasza niosącego Anchizesa.

Natomiast tożsamość bohaterów pokazanych na denarach M. Herenniusa jest dyskutowana. Niektórzy uznają, że - co proponował już Andreas Alföldi - przedstawiają one Eneasza $z$ Anchizesem ${ }^{18}$. Zwolenników ma również - w ślad za Theodorem Mommsenem i Ernestem Babelonem - dostrzeganie $\mathrm{w}$ ikonografii tych monet jednego z Braci Katańskich niosącego na ramieniu rodzica ${ }^{19}$. Jednakże to drugie rozwiązanie stawia pod znakiem za-

${ }^{15}$ RRC, 308/1a-b (108 lub 107 r. p.n.e., Rzym); CRR, s. 77, 567-568 (101 r. p.n.e., Regium?); BMCRR Rome, s. 195-196, 1231-1258 (ok. 91 r. p.n.e.). W sprawie datacji por. też H. Zehnacker, Moneta. Recherches sur l'organisation et l'art des émissions monétaires de la République romaine (289-31 av. J.-C.), Rome 1973, s. 656-657, 659.

${ }^{16}$ Zwracają na to podobieństwo uwagę np. A. Dubourdieu, Les origines, s. 205; C. Perassi, I pii fratres e il pius Aeneas problemi circa l'iconografia di monete della Sicilia e dell'età repubblicana romana, Aevum 16, 1, 1994, s. 82-83; I. Bitto, M. Herennio, il mito eneico, la dea Herentas, [w:] M. Caccamo Caltabiano, D. Castrizio, M. Puglisi (red.), La tradizione iconica, s. 385.

${ }^{17} \mathrm{~W}$ kwestii RRC 458/1 zob. np. J.D. Evans, The Art of Persuasion, s. 41; C. Perassi, I pii fratres, s. 74; B. Woytek, Arma et Nummi, s. 218-220; P. Berdowski, Pietas erga patriam: ideology and politics in Rome in the early first century B.C. The evidence from coins and glandes inscriptae, [w:] K. Twardowska et al. (red.), Within the Circle of Ancient Ideas and Virtues. Studies in Honour of Professor Maria Dzielska, Kraków 2014, s. 158.

${ }^{18}$ A. Alföldi, Der neue Weltherrscher der vierten Ekloge Virgils, Hermes 65, 1930, s. 375, przyp. 1; P. Petrillo Serafin, La pietas di Enea: due monete a confronto, Bollettino d'Arte 13, 1982, s. 37-38, przyp. 20; I. Bitto, Per una proposta di interpretazione del denarius del monetiere M. Herennius con leggenda PIETAS, Messana 3, 1990, s. 147-168; eadem, M. Herennio, s. 385-388; J.D. Evans, The Art of Persuasion, s. 37; K. Kopij, Pietas in the Propaganda of Sextus Pompey, Studies in Ancient Art and Civilization 15, 2011, s. 204-205.

19 Th. Mommsen, Geschichte des römischen Münzwesens, Berlin 1860, s. 565-567, 185; E. Babelon, Description historique, 1, s. 538-539, Herennia 1; por. też F. Münzer, Herennius 46, [w:] G. Wissowa et al. (red.), Paulys Real-Encyclopädie der classischen Altertumswissenschaft 8,1 , Stuttgart 1912, szp. 679-680; RRC, 308/1a-b; CRR, s. 77, 567-568; BMCRR 1, s. 195-196, 1231-1258; G.G. Belloni, Le monete romane dell'età repubblicana, Milano 1960, s. 79 (niesie ojca); G.K. Galinsky, Aeneas, s. 54-55 i przyp. 105; W. Fuchs, Die Bildgeschichte, s. 624; C. ArnoldBiucchi, Amphinomos et Anapias, [w:] LIMC, 3; P. Aichholzer, Darstellungen römischer Sagen, s. 13-14; C. Perassi, I pii fratres, s. 76-78; C. Franzoni, Amphinomos e Anapias a Catania per la storia di due statue ellenistiche perdute, Kokalos 41, 1995, s. 213, 216 (niesie matkę); T. Mikocki, 
pytania tożsamość postaci $\mathrm{w}$ tak podobny sposób ukazanych na aureusach L. Livineiusa Regulusa (RRC 494/3), związanych z osobą młodego Cezara. Należałoby bowiem przyjąć, że również one odnoszą się do Braci Katańskich $^{20}$. W przypadku tych aureusów mogą również zastanawiać przyczyny rezygnacji ze starszego zaledwie o kilka lat wzorca, jaki dawały denary Cezara (RRC 458/1), a sięgnięcie do tak odległego, bo sprzed 60 lat, modelu stworzonego przez M. Herenniusa (RRC 308/1) ${ }^{21}$, by potem w latach pryncypatu Augusta na monetach z Segesty i z Ilium odejść od typu ikonograficznego używanego uprzednio dla Oktawiana w latach 40. I w. i nawiązać do ikonografii podobnej do tej na denarach Cezara. Właśnie mennictwo młodego Cezara, potem Augusta, jest - w zakresie wczesnej obecności Eneasza na numizmatach - najciekawsze, bowiem wykorzystano w nim, na emisjach z Rzymu (RRC 494/3), Segesty (RPC 1, 652) oraz Ilium (RPC 1, 2306), aż trzy różne warianty ikonografii. Żonglowanie nimi wskazuje, że odwoływano się do różnych odsłon wizerunku Eneasza, a także dowodzi intensywności działań skupionych wokół postaci Eneasza oraz jego ogromnej siły ideologicznej.

Eneasz wyniósł swego ojca Anchizesa z Troi. W ten sposób uratował go od niechybnie grożącej mu śmierci. Ten aspekt portretu Eneasza - pietas in patrem - wcześnie stał się jedną z jego prymarnych cech ${ }^{22}$. Już najstarsze

Zgodna, pobożna, płodna, skromna, piękna... Propaganda cnót żeńskich w sztuce rzymskiej, Wrocław 1997, s. 109 (niesie ojca); E.M. Zarrow, Sicily, s. 131; C. Soraci, L’Etna e le Eolie. L'emergenza vulcane e i provvedimenti messi in atto dal governo romano, Quaderni Catanesi di Studi Antichi e Medievali 3, 2004, s. 453-454; S. Estiot, Sex. Pompée, la Sicile et la monnaies. Problèmes de datation, [w:] J. Champeaux, M. Chassignet (red.), Aere perennius, en hommage à Hubert Zehnacker, Paris 2006, s. 142; E. Giampiccolo, La Miranda Fabula dei Pii Fratres: la leggenda, le monete, la statua, Rivista di cultura classica e medioevale 52, 1, 2010, s. 76; P. Berdowski, Pietas erga patriam, s. 146-148; idem, Sextus Pompeius i wojny domowe w Rzymie (49-35 r. p.n.e.), Rzeszów 2015, s. 137 (niesiona postać „najprawdopodobniej kobieca”), il. 1 („młodzieniec niosący na barku kobiecą postać”). Mniej jednoznaczne opinie: E. Deniaux, À propos des Herennii de la république et de l'époque d'Auguste, Mélanges de l'Ecole française de Rome, Antiquité 91, 2, 1979, s. 648 (postać ma także cechy Eneasza); A. Dardenay, Images, s. 15: „plutôt un des jeunes héros de Catane”, E2 (w opisie monety „un des frères de Catane sauvant son père de l'éruption de l'Etna”, ale jednak umieszcza ją w grupie źródeł obrazujących „La fuite d'Enée").

${ }^{20}$ Zwolennikami takiej interpretacji są np. E.M. Zarrow, Sicily, s. 130-135; C. Soraci, L'Etna, s. 454. Wątpliwości wyraża P. Berdowski, Sextus Pompeius, s. 326-328 (przywoływany na tych stronach jest oczywiście A. Alföldi, nie Alföldy).

${ }^{21}$ Formułuje się przypuszczenie, że Regulus znał tylko monety Herenniusa, dlatego powrócił do tego wzorca, por. A. Dardenay, Images, s. 17.

${ }_{22}^{2}$ Nie była to jego jedyna cecha: Eneasz był nie tylko pius, był także wojownikiem, niekiedy pomagał Parysowi w uprowadzeniu Heleny, a czasem był uważany za zdrajcę. Co więcej, nie zawsze sprostał, kiedy jego pietas, rozumiana jako powinność wobec ojczyzny i powolność wobec woli bogów, była wystawiana na próbę, por. np. Verg., Aen. 4.193-194, 267. Złożoność wizerunku Eneasza - N.M. Horsfall, The Aeneas Legend, s. 13-14. 
znane jego przedstawienia $\mathrm{w}$ malarstwie wazowym pokazują go z Anchizesem na plecach lub na ramieniu ${ }^{23}$. Również autorzy starożytni zaczęli odmalowywać postać bohatera, zwracając uwagę wprost na jego eusébeia - pietas - postawę tę widząc $\mathrm{w}$ akcie wyniesienia rodzica na własnych barkach ${ }^{24}$. W tradycji rzymskiej podjęto wątek tego brzemienia ojcowskiego, pondera paterna (Ov., Fast. 1.534), a Eneaszowa pietas stała się toposem ${ }^{25}$. W epoce Augusta pogłębiono wymiar tej cnoty Eneasza. Warto tu przywołać aktualność tego, co kryło się pod pojęciem pietas, w latach zamętu politycznego i walki wewnętrznej u schyłku Republiki. Objaśniał to post factum Appian z Aleksandrii. Opisując akcje proskrypcyjne 43 r. p.n.e., przywołał przykład niejakiego Oppiusa, który uratował swego starego i słabego ojca, wynosząc go na plecach, i bezpiecznie doprowadził na Sycylię. Dalej Appian porównał jego czyn do czynu Eneasza (App., Bell. civ. 4.41). Echo takiego pojmowania obowiązków syna wobec rodzica w sytuacji wymagającej sporej odwagi, a także nastrojów oraz rozterek targających jednym i drugim pobrzmiewa w „Eneidzie”. Anchizes wzbrania się przed tułaczką, powiada do swych bliskich: „uos agitate fugam” (Verg., Aen. 2.640, „Wy chrońcie się ucieczką”). Syn natomiast obarcza się jego ciężarem, świadomy dodatkowych trudów i niebezpieczeństwa: „nunc omnes terrent aurae, sonus excitat omnis/suspensum et pariter comitique onerique timentem" (Verg., Aen. 2.728-729, tłum. T. Karyłowski: „Na wietrzyk, na dźwięk każdy pierś trwogą się ściska/ i lękiem: drżę o druha i ciężar pospołu”). To tylko jeden ze sprawdzianów pietas Eneasza. Przecież - co pokazywały różne epizody jego życia - jego pietas realizowała się nie tylko wobec bliskich (erga parentes), ale też w stosunku do bogów (erga deos) oraz ojczyzny (erga patriam) ${ }^{26}$. Aż po epokę późną dominujący rys wizerunkowi bohatera trojańskiego nadawała owa pietatis sarcina (OGR 9.1), przy czym w ikonografii monetarnej w ogóle, ale

\footnotetext{
${ }^{23}$ Malarstwo czarnofigurowe, fragment amfory, Reggio Calabria, 540 r. p.n.e. - F. Canciani, Aineias, 59; kylix z Vulci, 530 r. p.n.e., ibidem, 60; amfora $z$ Vulci, 520/510 r. p.n.e.; ibidem, 61 itd. Inaczej: Anchizes kroczący za Eneaszem - dekoracja lekythosu z Geli, 480/470 r. p.n.e., metopa $28 \mathrm{~N} \mathrm{z}$ Partenonu, 447-438 r. p.n.e., por. W. Fuchs, Die Bildgeschichte, s. 619-620; F. Canciani, Aineias, 155-156.

${ }^{24}$ Soph. Laocoon, fragment 373 = Dion. Hal., 1.48.2; Xen., Cyn. 1.15; Lyc., Alex. 1270; o bogobojności bohatera pisał także Hom., Ill. 20, 297-300.

${ }^{25} \mathrm{~W}$ takiej funkcji wątek pius Aeneas włączony w Rhet. ad Her. 4.34.46.

${ }^{26}$ Wymowne są słowa Cycerona (Cic., De inv. 2.66): „religionem eam, quae in metu et caerimonia deorum sit, appellant, pietatem, quae erga patriam aut parentes aut alios sanguine coniunctos officium conservare moneat” (tłum. K. Ekes: „Bogobojnością ludzie nazywają to, na co składają się bojaźń i cześć dla bogów. Wzniosła miłość to uczucie, które nakazuje pełnić obowiązki wobec ojczyzny, rodziców bądź innych ludzi, złączonych z nami więzami krwi”).
} 
zwłaszcza we wczesnej fazie obecności Eneasza pietas trojańskiego uchodźcy definiowano niemal wyłącznie poprzez dopełnienie jego sylwetki figurą niesionego Anchizesa.

Z kolei znani szeroko Bracia Katańscy, kiedy pewnego czasu wybuchła Etna, uratowali swych rodziców, wynosząc ich na swych barkach $\mathrm{z}$ miasta Katana (Katane, Catina). Pierwszy z nich, Amphinomos (Amphinomus), ratował w ten sposób ojca, a drugi - Anapias - matkę:

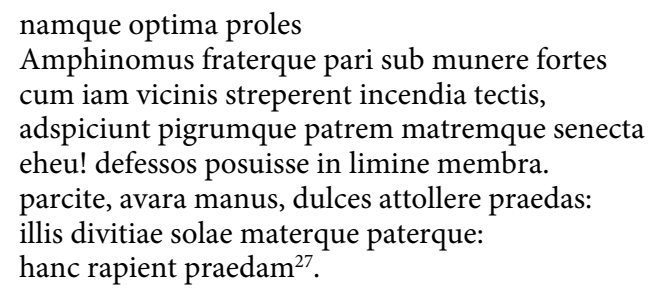

Wspominali tę historię liczni autorzy starożytni ${ }^{28}$, niekiedy przydając inne imiona jej bohaterom. W „Fabulae” Hyginusa (254.4) nazywani są oni Damon i Phyntia, według Solinusa (5.15) w Syrakuzach znano ich pod imionami Emantias i Criton, z kolei według innych byli to Philonomos i Kallias (Ael. ap. Stob., Flor. 79.38). Swą odważną postawą bracia dali przykład poświęcenia i spełnienia obowiązku wobec rodziców ${ }^{29}$. Pamięć o nich przetrwała i dała pewną sławę miastu Katana ${ }^{30}$. Opodal samej Katany (apud Catinam Cl. Claud., Carm. min. 17) wznosiła się rzeźba przedstawiająca braci. Pewne

${ }^{27}$ Aetna 625-632, tłum. S. Śnieżewski: „Albowiem, najlepsze potomstwo,/Amfinomus i jego brat, dzielnie stawiając czoła/jednakowemu obowiązkowi, gdy pożary czynią już spustoszenie w sąsiednich domach,/widzą, jak powolni ze starości ojciec i matka,/ach!, wyczerpani, upadli bezsilnie na progu./Przestańcie, zachłanna gromado, unosić łupy bogate!/Dla tych jedynym bogactwem matka i ojciec,/tę właśnie zdobycz porywają".

${ }^{28}$ Lycurg., Orat. in Leocr. 95-97; De mirabilibus auscultationibus 154; Con., Dieg. 43; Strab., 6.2.3; Val. Max., 5 ext. 4; Aetna 603-645; Sen., Ben. 3.37 .2 i 6.36; Hyg., Fab. 254.4; Mart., 7.24.5-6; Sil. Ital., 14.196-197; Paus. 10.28.4; Apul., de Mundo 34.365; Philostr., V. Apoll. 5.17; Sol. 5.15; Aus., Ordo V. nob. 16; Stob., Serm. 77; Cl. Claud., Carm. min. 17; Anth. Pal. 3.7; Phot., Bibl. 186, 139b. Por. F. Morgano, La leggenda dei pii fratres, Archivio Storico per la Sicilia Orientale 31, 1935, s. 108-112; C. Franzoni, Amphinomos, s. 211-212; E. Giampiccolo, La Miranda Fabula, s. 70-79; S. Santelia, La miranda fabula dei pii fratres in Aetna 603-645, Bari 2010, s. 21-44. Nie można umiejscowić zdarzenia w czasie. Dyskusja dotyczy też czasu wykształcenia się tej legendy. Już S. Mirone przypominał, że w epoce rzymskiej Etna wielokrotnie wybuchała, S. Mirone, Le monete dell'antica Catana, RIN 31, 1918, s. 53. Sugerował, iż legenda zrodziła się już w okresie poprzedzającym obecność grecka na Sycylii, por. idem, Le monete coniate in Catania in memoria dei Pii Fratres, RIN 29, 1916, s. 226.

${ }^{29}$ Por. Aetna, s. 633-634: „O maxima rerum/et merito pietas homini tutissima virtus!” (tłum. S. Śnieżewski: „O największa z rzeczy, poczucie obowiązku wobec rodziców,/słusznie - wśród innych cnót - uważane za najpewniejsze ocalenie dla człowieka!”).

${ }^{30}$ Sil. Ital., 14.197; Auson., Ordo V. nob. 16.2; IG XIV 502. 
zaś miejsce - na ich cześć - nosiło nazwę Campus Piorum (Sol. 5.15; por. Philostr., 5.17) i kryło także ich grobowiec czy cenotaf (sepulcri locus - Sol., 5.15) bądź monument będący rodzajem heroonu (por. Con., Dieg. 43: mnémeion). Historia Braci Katańskich znana była również na Wschodzie. Mianowicie anonimowy epigram (Anth. Pal. 3.17) informuje, że nawiązywał do niej stylopinakion w świątyni w Kyzikos. Wznieśli ją przed 159 r. p.n.e. Attalos II i Eumenes II, dedykując swej matce Apollonis, wdowie po władcy pergamońskim Attalosie I ${ }^{31}$. Już samą tę budowlę można zatem traktować jako wyraz utrwalonej publice synowskiej pietas, niemniej motyw Braci Katańskich włączony do dekoracji świątyni również sam w sobie mogł tę pietas alegoryzować32.

Starożytni wskazywali mocną nić wiążącą Eneasza, który był pius/eusebéstatos, oraz Pii Fratres. Pierwszego i drugich stawiali jako przykłady tych, którzy „ratowali swych ojców w niebezpieczeństwie”: „(...) exempla sunt eorum, qui parentes suos periculis eripuerint, qui ex infimo ad summum protulerint" ${ }^{\prime 3}$. Odnajduje się także pewne ogólne podobieństwo monetarnych wizerunków Eneasza oraz Braci Katańskich. Do czynu Amphinomusa i Anapiasa nawiązywano bowiem na monetach $z$ Katany ${ }^{34}$. Przedstawiając symbolicznie scenę ocalenia przez nich rodziców, skomponowano wyobrażenia awersu i rewersu w taki sposób, by obie strony monety przedstawiały po jednym z braci, odpowiednio każdego z ojcem lub matką (por. il. 9) ${ }^{35}$. Alternatywnie pokazano ich wspólnie na rewersach w antytetycznym układzie w jed-

${ }^{31}$ Apollonis lub Apollonias, zob. Strab., 13, s. 624-625; Plut., De frat. am. 5; Polyb., 22.20; Suida, s.v. Apollonias. Por. F.H. Massa-Pairault, Il problema degli stylopinakia del tempio di Apollonis a Cizico. Alcune considerazioni, Annali della Facoltà di Lettere e Filosofia, Università degli studi di Perugia 19, 1981-1982, s. 149-219.

32 Por. S. Santelia, La miranda fabula, s. 34, przyp. 25.

${ }^{33}$ Sen., Ben. 3.38.1, tłum. L. Joachimowicz. Zob. też Hyg., Fab. 254.4; Sen., Ben. 3.37.1-2; Cl. Claud., Carm. min. 17 (przykład braci z Argos: Kleobis i Biton sami wprzęgli się pod jarzmo i ciągnęli wóz, na którym siedziała ich matka, i w ten sposób przybyła ona do świątyni, por. Hdt. 1.31).

${ }^{34} \mathrm{Nie}$ ma konsensusu w kwestii chronologii powstania tych monet. Por. CNS 3, Katane, s. 97-98 oraz I. Bitto, Per una proposta, s. 149 (II-I w. p.n.e.); B. Carroccio, Dal basileus Agatocle a Roma. Le monetazioni siciliane d'età ellenistica (cronologia - iconografia - metrologia), Messina 2004, s. 48 (190-86 r. p.n.e.). Por. inne propozycje: B.V. Head, Historia, s. 117; C. Arnold-Biucchi, Amphinomos, 1 i 2 (k. III-II w. p.n.e.); S. Mirone, Le monete coniate, s. 228 (po 212 r. p.n.e.). Odnośnie do dolnej granicy chronologicznej tych emisji por. G. Manganaro, La monetazione di Katane dal V al I sec. a.C., [w:] B. Gentili (red.), Catania antica, Roma 1996, s. 314, 316 (ostatnia emisja: pocz. I w. p.n.e., ale „Ancora più tardi, intorno al 20 d.C., su logori sesterzi e dupondii di Augusto furono apposte contromarche col tipo del Pius Frater, anche due volte, certamente a Catana, come avvenne in altre città siciliane nel contempo impiegando tipi diversi" (ibidem, s. 319); komentarze - G. Guzzetta, La monetazione, s. 188-189.

${ }^{35}$ BMCG Sicily, Catana, s. 52-53: 74-79; CNS 3, Katane, s. 99-100, 11-13/8. 
nej scenie, każdego obarczonego rodzicem (por. il. 10) ${ }^{36}$. Natomiast na poszczególnych monetach, powstałych przy użyciu różnych stempli, aranżacja póz, gestów, strojów tych czterech postaci jest różna, co w drobiazgowej analizie wykazuje Eleonora Giampiccolo ${ }^{37}$. Bracia mogą być ukazani nago, czasem ich plecy okrywają rozwiane płaszcze, a czasem taką chlamidę nosi tylko jeden $\mathrm{z}$ nich. Rodzice są niesieni na ramionach, synowie ich dodatkowo podtrzymują dwoma albo jedną ręką. Niekiedy synowie unoszą rodziców w ramionach. Ojciec na niektórych egzemplarzach monet trzyma długi przedmiot, prawdopodobnie laskę, na innych - wydaje się - rodzice trzymają się za ręce. Matka w długiej szacie, niekiedy nosi na głowie woal albo to jej fryzura przyjmuje taki okrągły kształt, natomiast ręce unosi ona w błagalnym geście.

Zauważa się zbieżność, a co najmniej podobieństwo, niektórych detali ikonografii monetarnej z ékphrasis brązowej rzeźby przedstawiającej Braci Katańskich apud Catinam, sporządzonej przez Klaudiusza Klaudianusa (Carm. min. 17$)^{38}$. Nasycił on szczegółami opis zabytku: dramatyczne gesty rodziców niesionych przez synów, ojciec wskazuje na płomienie („saeva senex incendia monstret", 17.9), matka z włosami w nieładzie otwiera usta, wzywając pomocy („ut trepido genetrix invocet ore deos?/erexit formido comam”, 17.10-11), chlamidy braci rozwiewa wiatr („reiectae vento chlamydes”, 17.15), jeden $\mathrm{z}$ nich niesie ojca, potrzymując go prawym ramieniem („dextram exerit ille/ contentus laeva sustinuisse patrem", 17.15-16), drugi oburącz trzyma matkę (,ast illi duplices in nodum colligit ulnas/cautior in sexu debiliore labor”), ich obliczom nadano podobieństwa do twarzy rodziców („hic propior matri fit tamen, ille patri/dissimiles annos sollertia temperat artis:/alter in alterius redditur ore parens", 17.22-24). Autor ten opisywał rzeźbę, która istniała w IV/V w. ${ }^{39}$ i którą - niewykluczone - może osobiście podziwiał. Trudno

${ }^{36}$ BMCG Sicily, Catana, s. 52-53: 70-73; CNS 3, Katane, s. 97-98, 10-10/13.

${ }^{37}$ E. Giampiccolo, La Miranda Fabula, s. 71-79. Przebadała 61 egzemplarzy; przy ich produkcji użyto 56 stempli rewersu i 60 stempli awersu.

${ }^{38}$ To wiodło do wniosku, że na monetach wyobrażono grupę rzeźbiarską znaną z opisu późnego autora: S. Mirone, Le monete coniate, s. 233; C. Franzoni, Amphinomos, s. 220; por. C. Perassi, I pii fratres, s. 60-63.

${ }^{39}$ Jej późniejsze losy częściowo naświetla treść inskrypcji wyrytej na marmurowej bazie (Museo Civico di Catania, Magazzino del Cortile): „[fl]amm[i]fugas fratre[s]/pietatis maxima dona/quos tulit hostilit[as]/reddidit hos Merulus v(ir) [c(larissimus)]/et spectabilis consul[aris]/provinciae Siciliae" - AE 1956, 259; S. Mazzarino, I Vandali a Catania (a proposito di una nuova epigrafe catanese). Rivista del comune di Catania 4, 1954, s. 111-114 (po 479 r.); K. Korhonen, Le iscrizioni del Museo Civico di Catania. Storia delle collezioni - Cultura epigrafica - Edizione, Helsinki 2004, s. $12,157$. 
bowiem przyjąć, że bazował na oglądzie wyobrażeń dawnych monet i na ich podstawie dał tak detaliczną descriptio posągów Braci Katańskich ${ }^{40}$.

Monument symbolizujący bohaterski czyn Braci stał znacznie wcześniej ${ }^{41}$. Za jego dawnością przemawia wzmianka Konona, autora z czasów Augusta, o upamiętnieniu pietas Braci Katańskich w formie materialnej: w marmurze (Con., Dieg. 43) ${ }^{42}$. Autorami inicjatywy byli, jak podał Konon, Sikeliôtai, zatem nie sami tylko mieszkańcy Katany, co przekonuje o szerszej popularności opowieści i uznaniu dla jej bohaterów. Również wskazane wyżej emisje monetarne $\mathrm{z}$ Katany dowodzą, że przetwarzano $\mathrm{w}$ różne obrazy monetarne kompozycję oraz treść ideową owej rzeźby. W ikonografii tych monet charakterystycznymi, chociaż różnymi rozwiązaniami obrazowano ideę poświęcenia Braci dla ich rodziców.

Jednakże w mennictwie temat Braci Katańskich podejmowano rzadko. Oprócz przywołanych wyżej monet z Katany można wskazać denary Sekstusa Pompejusza (Sex. Pompeius) (por.il. 11) ${ }^{43}$ oraz replikujące je denary wyemitowane $\mathrm{w}$ serii nummi restituti wypuszczonej za rządów cesarza Trajana ${ }^{44}$. W ikonografii tych monet motyw Braci Katańskich został mocno zmieniony. Tym razem pokazano ich w polu głównym rewersu, na plecach i Anapiasa, i Amphinomusa powiewa chlamida, oburącz każdy z nich podtrzymuje rodzica siedzącego na ich ramieniu, matka unosi obie ręce, ojciec zaś - zdaje się - wskazuje coś gestem wyciągniętej ręki. Są tu więc rozwiązania znane także $\mathrm{z}$ monet $\mathrm{z}$ Katany. Jednak największą zmianą jest wmontowanie $\mathrm{w}$ wyobrażenie przedstawienia Neptuna, który stoi z aplustre w prawicy, ze stopą opartą

${ }^{40}$ Fragmenty innego dzieła Klaudiusza Klaudianusa, De raptu Proserpinae (1.158-176), pisane ok. 395-397 r., w których dał on realistyczną charakterystykę Etny, sugerują, że autor ten znał opisywane miejsca na Sycylii. Nie wydaje się, by szczegóły wprowadzone do opisu rzeźby Braci Katańskich, np. podobieństwo rodzinne twarzy jej bohaterów, mógł on dostrzec na monecie. Por. C. Franzoni, Amphinomos, s. 219.

${ }^{41}$ Por. rozważania na temat dwóch rzeźb Braci Katańskich: C. Franzoni, Amphinomos, zwł. s. 217-221, oraz pogląd, że monety Herenniusa inspirowane były grupą rzeźbiarską „späthellenistische Bronzegruppe”, a brązy z Katany mogą powtarzać model „ältere Steingruppen”: W. Fuchs, Die Bildgeschichte, s. 626.

${ }^{42}$ Por. opinia, iż Konon odnosił się do innej lokalizacji niż kilka wieków po nim Klaudiusz Klaudianus - E. Giampiccolo, La Miranda Fabula, s. 73.

${ }^{43}$ Aw. MAG PIVS IMP ITER, głowa Pompejusza Wielkiego, lituus; Rw. PRAEF CLAS ET ORAE MARIT EX S C, Neptun, Bracia Katańscy - BMCRR, Sicily, s. 560, 7, 11 (42-38 r. p.n.e.); RRC, 511/3 (42-40 r. p.n.e.); CRR, 1344-1345 (43-36 r. p.n.e.); C. Arnold-Biucchi, Amphinomos, 4 (42-40 r. p.n.e.); por. L. Morawiecki, Władza charyzmatyczna w Rzymie u schyłku republiki (lata 44-27 p.n.e.), Rzeszów 1989, s. 68-88; S. Estiot, Sex. Pompée, s. 127-153: 42-39 r. p.n.e.; A. Dardenay, Les mythes, s. 46; P. Berdowski, Sextus Pompeius, s. 306-307 i 324.

${ }^{44}$ BMCRE 3, Tr., s. 137, 693; H. Komnick, Die Restitutionsmünzen, 47.0; B. Woytek, Die Reichsprägung, 847. 
na prora. Nie jest to więc efekt odtwórczego posługiwania się wzorem dostarczanym przez monument rzeźbiarski upamiętniający Braci Katańskich. To jego swobodna interpretacja monetarna, a może zmiksowanie w tej interpretacji treści dwóch zabytków, jednego honorującego Braci Katańskich i drugiego, przedstawiającego Neptuna ${ }^{45}$.

W zestawieniu z brązami z Katany, denarami Pompeiusa oraz denarami restytucyjnymi, które bez wątpienia przedstawiają Amphinomusa i Anapiasa, aranżacja wyobrażenia na rewersach denarów republikańskich M. Herenniusa (RRC 308/1), chociaż zachowuje pewne ideowe podobieństwo, jest inna. Nie jest oczywiste, że obrazują one jednego z braci. Tym bardziej, biorąc pod uwagę szerszy kontekst, Braci Katańskich nie pokazywały związane z młodym Cezarem aureusy L. Livineiusa Regulusa RRC 494/3. Wspólne cechy wyobrażeń monet RRC 308/1 i RRC 494/3, jednocześnie ich odmienność od funkcjonującego wówczas wyobrażenia monetarnego Braci Katańskich oraz odnajdywane ich podobieństwo do ujęć tak Braci Katańskich, jak Eneasza mogą sugerować, że oba $\mathrm{z}$ tych dwóch wyobrażeń można odczytywać jako signum pietatis. Inspiracji, owszem, mógł dostarczyć model Braci Katańskich, czy to $\mathrm{w}$ formie rzeźby, czy stempla monetarnego lub monety, ale jeśli tak było, to został on mocno zmieniony i w rezultacie oddalono się od pierwowzoru. Obraz na monetach M. Herenniusa i L. Livineiusa Regulusa jest bowiem na tyle niejednoznaczny, że zdaje się, iż ilustruje ogólniejszą wartość, pietas, którą ucieleśniali zarówno Bracia Katańscy, Pii Fratres, jak i Eneasz, Aeneas pius. To chyba nawet dla ówczesnych nie było proste do rozróżnienia na bazie wyobrażeń prezentowanych na tych numizmatach. Współcześnie próby rozstrzygnięcia tożsamości bazują na argumentach wspieranych tradycją ikonograficzną dotyczącą Eneasza, skromną w okresie przedwergiliańskim, a także na rozpoznanych mniej lub bardziej trafnie okolicznościach politycznych, które mogły skłonić do wyboru bądź motywu Eneasza bądź Braci Katańskich. Faktem jest, że schemat Eneasza niosącego na plecach rodzica był analogiczny w ikonografii i mógł być podobny wymowie do rewersów przedstawiających jednego z Braci Katańskich ${ }^{46}$.

${ }^{45}$ Por. G. Manganaro, La monetazione, s. 319: może inspirowano się rzeźbą przedstawiającą Braci Katańskich; z kolei E. Giampiccolo, La Miranda Fabula, s. 76: denary mogły być ikonograficznie zależne nie od posągu, ale od jakiegoś egzemplarza monet. Motyw ten stał się jednym $\mathrm{z}$ monetarnych symboli Katany.

${ }^{46}$ Trzeba założyć możliwy wzajemny wpływ przedstawień Eneasza na monetach z Segesty oraz Braci Katańskich na monetach z Katany, niestety chronologia tych emisji jest mało precyzyjna. Trudno też rozstrzygnąć, czy przedstawienie jednego z Braci zasugerowało obraz Eneasza w mennictwie doby późnorepublikańskiej, czy też odwrotny był kierunek zależności. 
Przedstawienia bohatera trojańskiego niosącego ojca, wprowadzone na wskazane wyżej, trudne do bezwzględnego wydatowania brązy z Segesty, funkcjonowały potem dopiero $\mathrm{w}$ mennictwie republikańskim okresu schyłkowej Republiki. Niemniej Eneasz jako portans wystąpił już w najstarszym znanym swym monetarnym przedstawieniu. Mianowicie na rewersy tetradrachm z Aineia w Chalcydyce z początku V w. p.n.e. wprowadzono obok inskrypcji AINEA $\Sigma$ obraz dwóch postaci kierujących się w prawo, niosących dwie inne postacie na ramionach (por. il. 12) ${ }^{47}$. Jeden z kroczących to Eneasz, który trzyma na ramieniu Anchizesa, ten niekiedy unosi rękę. Obok Eneasza podąża kobieta; idzie ona przodem, ale z głową zwróconą ku Eneaszowi, niesie syna (Askaniusza) albo - co wydaje się trafniejszym odczytem tego fragmentu wyobrażenia - córkę ${ }^{48}$. Rewers przedstawia scenę symbolicznego przybycia założyciela miasta do Aineia ${ }^{49}$. Atrybutem trojańskiego bohatera pozostaje tu niesione na ramieniu ludzkie brzemię. Podobnie jak w przypad$\mathrm{ku}$ jego towarzyszki $\mathrm{z}$ dzieckiem uwaga została tu skierowana $\mathrm{w}$ stronę postawy wobec członków rodziny. Nie jest to identyczna kompozycja jak ta ilustrująca epizod z historii Braci Katańskich. Ci kroczą w przeciwnych kierunkach, czyli inaczej niż para z Ainea podążająca w jedną stronę. Natomiast

\footnotetext{
${ }^{47}$ Monety znane od dawna, chociaż są tylko trzy egzemplarze. Datacja za M. Price, N. Waggoner, Archaic Greek Coinage. The Asyut Hoard, London 1975, s. 43-44: 194 (490-480 r. p.n.e.); por. też E. Babelon, Traité des monnaies grecques et romaines, 2, 1, Paris 1907, 1556; H. Gaebler, Die antiken Münzen Nord-Griechenlands, 3. Makedonia und Paionia, 2, Berlin 1935, s. 20-21 (od końca VI w. do 480 r. p.n.e.), 1; R. Texier, A propos de deux représentations, s. 16-18; Th.S. Duncan, The Aeneas Legend, s. 24 (ok. 550 r p.n.e.); A. Alföldi, Die trojanischen Urahnen, s. 17; G.K. Galinsky, Aeneas, s. 111-112 (przed 525 r. p.n.e.); W. Fuchs, Die Bildgeschichte, s. 617-618 (ok. 500 r. p.n.e.); F. Canciani, Aineias, 92; por. P. Aichholzer, Darstellungen römischer Sagen, s. 8-10; N.M. Horsfall, The Aeneas Legend, s. 12-13; I. Bitto, Per una proposta, s. 150. Zakłada się, że wzorca tym wyobrażeniom monet z Aineia dostarczyło malowidło lub rzeźba: A. Dardenay, Les mythes, s. 46-47.

${ }^{48}$ Syn - M. Price, N. Waggoner, Archaic Greek Coinage, s. 10-11 i 43-44; M. Caltabiano, Gli eroi, s. 28, tab. 1, 1; M. Krumme, Römische Sagen, s. 95. Córka - Th.S. Duncan, The Aeneas Legend, s. 24: podaje imię Anthemone; F. Canciani, Aineias, 92; A. Dardenay, Les mythes, s. 46: tradycja nie przekazała imienia córki, wątpliwe, by niesiona była Afrodyta, matka Eneasza. Nie rozwijając tu tej kwestii, warto wspomnieć, że towarzyszka Eneasza jest identyfikowana w literaturze jako Kreuza.

${ }^{49}$ Według tradycji - Hegesinax z Aleksandrii w Troadzie (Cephalon Gergithien) i Hegesippos z Mekyberny - Aineia była założona przez Eneasza po jego ucieczce z Troi, tu zakończył on życie FGrHist IA nr 45F7; FGrHist III B, nr 391; Dion. Hal., 1.49.1 i 4; miał też według Dionizjosa z Halikarnasu pozostawić tych, którzy zmęczeni byli żeglugą. Zob. też Liv., 40.4.9. Por. A. Ballabriga, Survie et descendance d'Énée, Kernos 9, 1996, s. 32-33. Również w okresie późniejszym wizerunek Eneasza na monetach z Aineia: głowa z brodą i w hełmie - np. BMCG Macedonia, Aeneia, s. 41, 1-4; H. Gaebler, Die antiken Münzen, s. 21, 2-5; M. Mielczarek, Mennictwo starożytnej Grecji. Mennictwo okresów archaicznego i klasycznego, 1, Warszawa-Kraków 2006, s. 89; głowa w czapce frygijskiej - np. BMCG Macedonia, Aeneia, s. 42, 5; H. Gaebler, Die antiken Münzen, s. 22, 8-10, ale por. E. Babelon, Traité, 2, 4, Paris 1926, 927-930: Askaniusz.
} 
obecność takiej sceny na monetach z Aineia wskazuje na odległą w czasie praktykę prezentowania Eneasza w ikonografii monetarnej, która w istocie powróciła, choć w zmienionej postaci, po upływie wieków. Jest to o tyle znaczące, że przecież różny był kontekst ukazywania bohatera trojańskiego na numizmatach greckich i rzymskich, podobnie zmieniały się akcenty w wizerunku Eneasza przywoływane w mennictwie, ale także wyrażane w dziełach sztuki antycznej i przez autorów starożytnych. Mimo tej dynamiki cechującej obecność motywu Eneasza w mennictwie, sztuce i literaturze w wyobrażeniach monetarnych niemal zawsze pozostawał on tym, który na swych barkach czy na ramieniu dźwiga Anchizesa.

U schyłku Republiki temat Eneasza został zaktualizowany dzięki spektakularnej pozycji Cezara. W mennictwie tegoż zyskał wymiar nie tyle genealogiczny, ile polityczny. Eneasz jest bowiem na denarii Cezara przede wszystkim strażnikiem palladium oraz sacra niesionych przez Anchizesa. Taką rolę zyskuje Eneasz również na monetach z czasów Augusta. W efekcie można dostrzegać w tych obrazach Eneasza parafrazę roli Cezara i Augusta, którzy w latach - i po latach - wojen domowych spełniają wobec Rzymu podobną misję jak Eneasz, który wyrwawszy się z zamętu wojennego, dotarł do Lacjum, założył tu miasto i opiekował się nim.

Inaczej można określić sens treści aurei L. Livineiusa Regulusa z wczesnego okresu funkcjonowania Oktawiana na scenie politycznej. W odniesieniu do tej fazy jego obecności w życiu państwowym starożytni zauważyli pietas, jaką młodzieniec wykazywał w stosunku do ojca: ,adulescens summa pietate et memoria parentis sui" (Cic., Phil. 13.20.47), ale również pisząc o nim: „singulari pietate adulescens” (Cic., Phil. 13.20.46) oraz „pietas (...) iusta per arma" (Ov., Fast. 3.710) ${ }^{50}$. W tym kontekście nawiązanie na monetach budujących wizerunek Oktawiana czy to konkretnie do Eneasza, czy to do jednego z Braci Katańskich było kwestią pomniejszą ${ }^{51}$. Pierwszorzędną sprawą było bowiem przywołanie pietas erga parentes. Tu zarówno Eneasz, jak i Bracia Katańscy dostarczali inspiracji swą historią, a ich ikonograficzne ujęcia dobrych, przekonujących wzorców.

${ }^{50}$ Zob. także Ov., Fast. 3.709; 4.37; 5.569-570; Tac., Ann. 1.9.9; 1.10 .1 i 10.

${ }^{51}$ Por. C. Perassi, I pii fratres, zwł. s. 64-68, 76-78, 84: treści monet odnoszą się do pietas, ale niekoniecznie dotyczy ona siculos iuvenes lub Eneasza. Generalnie to pietas wobec rodzica. Por. też o monetach Herenniusa - A. Dardenay, Images, s. 15-16: na rewersie wyobrażenie jednego z Braci Katańskich służące pokazaniu pietas erga parentem, co uprawdopodobnia wyobrażenie Pietas na awersie. O kształtowaniu się sposobów wyrażania pietas w mennictwie: C. Perassi, La creazione di un tipo monetale il caso di pietas sulle emissioni romane di età repubblicana, Aevum 71, 1, 1997, s. 123-149; także T. Mikocki, Zgodna, s. 108-137. 


\section{ILUSTRACJE}

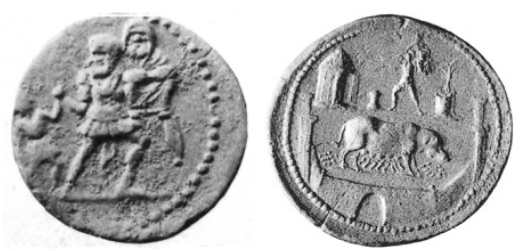

Il. 1. Æ, Ilium, II w., Rw.: Eneasz z Anchizesem i Askaniuszem, za: BMCG Troas, Ilium, 20, pl. XII 2

Il.2. ÆM, Rzym, Antoninus Pius, [138-161], Rw.: Eneasz z Anchizesem, tholos, ara, puteal, maciora z prosiętami, mury, za: F. Gnecchi, I medaglioni romani, descritti ed illustrati, 2, Milano 1912, 2, pl. 55.8

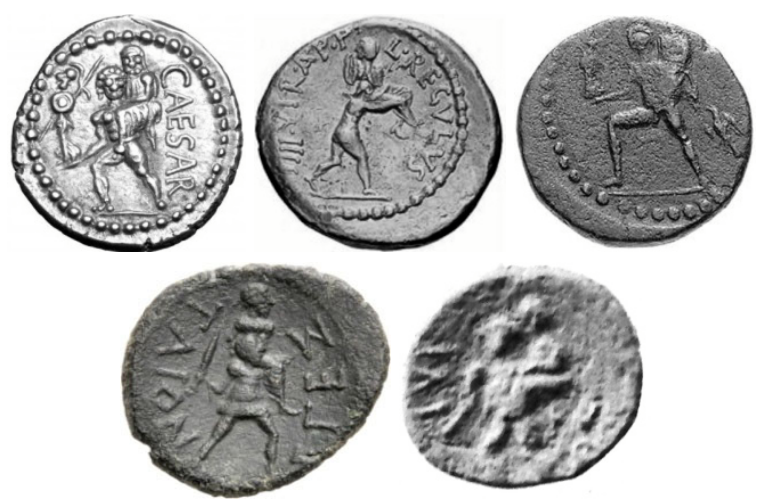

Il. 3. D, mennica: Afryka, 47-46 r. p.n.e., Rw.: CAESAR, Eneasz kroczy z palladium, niesie Anchizesa, zob. M.H. Crawford, Roman Republican Coinage, Cambridge 1974, 458/1

Il. 4. Au, Rzym, 42 r. p.n.e., Rw.: L REGVLVS IIIIVIR A P F, Eneasz niosący Anchizesa, zob. M.H. Crawford, Roman Republican Coinage, Cambridge 1974, 494/3

Il. 5. Æ, Segesta, August, 27-21 (?) r. p.n.e., Rw.: Eneasz niosący Anchizesa, w polu orzeł, zob. Roman Provincial Coinage, 1, A. Burnett, M. Amandry, P.P. Ripollès (red.), London-Paris 1992, 652

Il. 6. Æ, Segesta, okres rzymski, Rw.: $\Sigma$ EГE $\Sigma$ TAISN, Eneasz niosący Anchizesa, zob. R. Calciati, Corpus Nummorum Siculorum: la monetazione di bronzo, 1, Milano 1983, Segesta, 54

Il. 7. Æ, Ilium, August, 27-14 r. n.e., Rw.: I II, Eneasz z Anchizesem, za: BMCG Troas, Ilium, pl. XII 5 


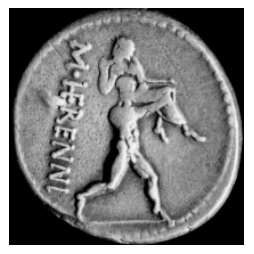

Il. 8. D, Rzym, koniec II w. p.n.e., Rw.: M HERENNI, postać męska kroczy w prawo, trzymając inną na lewym ramieniu, zob. M.H. Crawford, Roman Republican Coinage, Cambridge 1974, 308/1
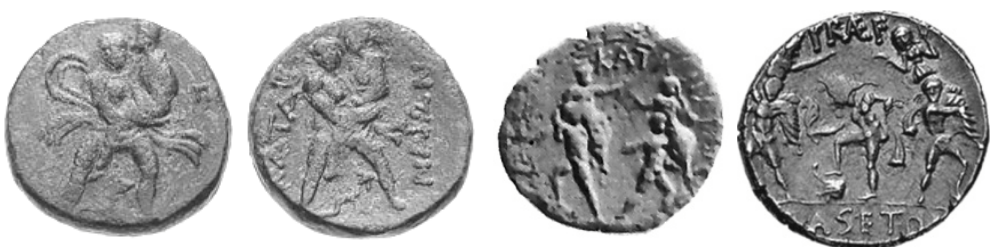

Il. 9. Æ, Katana, II-I w. p.n.e., Aw. Jeden z Braci Katańskich z ojcem; Rw. KATANAIQN, drugi - z matką, za: R. Calciati, Corpus Nummorum Siculorum: la monetazione di bronzo, 3, Milano 1987, 11/2

Il. 10. Æ, Katana, II-I w. p.n.e., Rw. Bracia Katańscy, za: R. Calciati, Corpus Nummorum Siculorum: la monetazione di bronzo, 3, Milano 1987, 10/12

Il. 11. D, mennica: Sycylia, 42-40 r. p.n.e., Rw.: PRAEF CLAS ET ORAE MARIT EX S C, Neptun, Bracia Katańscy, zob. M.H. Crawford, Roman Republican Coinage, Cambridge $1974,511 / 3$

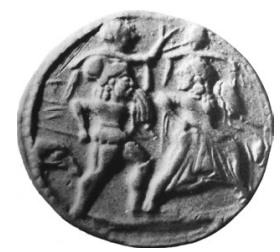

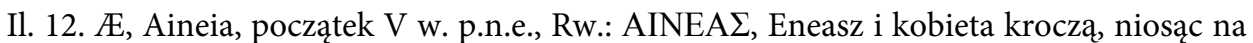
ramionach dwie inne postacie, za: M. Price, N. Waggoner, Archaic Greek Coinage. The Asyut Hoard, London 1975, pl. B 194 


\section{Agata A. Kluczek \\ AENEAS ANCHISIADES AND THE PII FRATRES. \\ REMARKS ON THE DEVELOPMENT OF THE EFFIGY \\ OF AENEAS IN ROMAN COINAGE}

\section{Summary}

Representations of Aeneas which appeared from 47-46 BCE to 14 CE in Roman coinage relied on a number of iconographic solutions. On the one hand, the motif was in its early stages and the topic representation of the fugitive from Troy and Roman progenitor was only developing at the time, hence the formal variations. On the other, this shows that the figure of Aeneas proved appealing to particular issuers or their principals - G. Julius Caesar and Octavian-Augustus.

These numismatic representations of Aeneas employed a variety of means to render the characteristics of the protagonist, including one of his chief qualities, namely pietas. As a result, a range of facets of the virtue would be drawn upon. Still, the depictions of Aeneas' pietas erga parentes bore substantial similarities to those of the Catanian Brothers.

The iconography in said coins focuses on the attitude of either Aeneas or the Catanian Brothers toward the members of their families. In this early stage of Aeneas's presence in Roman mintage, the Trojan hero was presented exclusively in the company of his father, Anchises. The latter was saved only due to his son's action, who carried him on his own shoulders. Aeneas, bearing the burden of his father, became an embodiment of pietas. This father-and-son relationship is symbolised by the representations in Caesar's denarii (47-46 BCE), the aurei of L. Livineius Regulus, who was affiliated with the young Caesar (42 BCE), bronzes from Segesta (27-21 BCE) and Ilium, dated to $27 \mathrm{BCE}-14 \mathrm{CE}$, and most likely in the much earlier republican denarii of M. Herennius (108 or $107 \mathrm{BCE}$ ) as well.

As far as the Catanian Brothers were concerned, they offered an example of the fulfilment of obligations toward their parents, in that they carried them safely away from the city of Catana which was burning following the eruption of Etna. Their deed was represented in a symbolic fashion - they were shown with their father and mother on their shoulders on the coins from Catana (until the 1st century BCE), on Sex. Pompeius's denarii (42-40 BCE) and then on the denarii restituti which were minted during Trajan's rule (ca. 112/113 CE).

The compositional similarity of coin reverses featuring both themes and the common ideological nature of their protagonists warrant the presumption that the aforementioned effigies of Aeneas sought to emphasize the latter's pietas. 


\section{Bibliografia}

A Catalogue of the Greek Coins in the British Museum, R.S. Poole (red.), London 1873-1927.

A Catalogue of the Roman Coins in the British Museum. Coins of the Roman Empire in the British Museum, H. Mattingly (red.), London 1965-1976.

$\mathrm{AE}=$ L'Année Epigraphique, Paris.

Aichholzer P., Darstellungen römischer Sagen, Wien 1983.

Alföldi A., Der neue Weltherrscher der vierten Ekloge Virgils, Hermes 65, 1930, s. 369-384.

Alföldi A., Die trojanischen Urahnen der Römer, Basel 1957.

Arnold-Biucchi C., Amphinomos et Anapias, [w:] L. Kahil (red.), Lexicon iconographicum mythologiae classicae, I, 1, Zürich-München 1981, s. 717-718.

Babelon E., Description historique et chronologique des monnaies de la République romaine vulgairement appelées monnaies consulaires, Paris 1885-1886.

Babelon E., Traité des monnaies grecques et romaines, Paris 1901-1926.

Ballabriga A., Survie et descendance d'Énée, Kernos 9, 1996, s. 21-36.

Belloni G.G., Le monete romane dell'età repubblicana, Milano 1960.

Berdowski P., Pietas erga patriam: ideology and politics in Rome in the early first century B.C. The evidence from coins and glandes inscriptae, [w:] K. Twardowska, M. Salamon, S. Sprawski, M. Stachura, S. Turlej (red.), Within the Circle of Ancient Ideas and Virtues. Studies in Honour of Professor Maria Dzielska, Kraków 2014, s. 143-159.

Berdowski P., Sextus Pompeius i wojny domowe w Rzymie (49-35 r. p.n.e.), Rzeszów 2015.

Bitto I., M. Herennio, il mito eneico, la dea Herentas, [w:] M. Caccamo Caltabiano, D. Castrizio, M. Puglisi (red.), La tradizione iconica come fonte storica: il ruolo della numismatica negli studi di iconografia, Reggio Calabria 2004, s. 385-398.

Bitto I., Per una proposta di interpretazione del denarius del monetiere M. Herennius con leggenda PIETAS, Messana 3, 1990, s. 147-168.

Calciati R., Corpus Nummorum Siculorum: la monetazione di bronzo, Milano 1983-1987.

Caltabiano M., Gli eroi omerici nella tipologia monetale antica, Rivista Italiana di Numismatica e Scienze Affini 90, 1988, s. 27-44.

Canciani F., Aineias, [w:] L. Kahil (red.), Lexicon iconographicum mythologiae classicae, I, 1, Zürich-München 1981, s. 381-396.

Carroccio B., Dal basileus Agatocle a Roma. Le monetazioni siciliane d'età ellenistica (cronologia - iconografia - metrologia), Messina 2004.

CIL = Corpus Inscriptionum Latinarum, Berolini-Paris 1863.

Crawford M.H., Roman Republican Coinage, Cambridge 1974.

Dardenay A., Images des Fondateurs. D’Enée à Romulus, Bordeaux 2012.

Dardenay A., Les mythes fondateurs de Rome. Images et politique dans l'Occident romain, Paris 2010.

Deniaux E., À propos des Herennii de la république et de l'époque d'Auguste, Mélanges de l'Ecole française de Rome, Antiquité 91, 2, 1979, s. 623-650.

Dubordieu A., Les origines et le développement du culte des Pénates à Rome, Rome 1989.

Duncan Th.S., The Aeneas Legend on Coins, The Classical Journal 44, 1948, s. 15-29.

Estiot S., Sex. Pompée, la Sicile et la monnaies. Problèmes de datation, [w:] J. Champeaux, M. Chassignet (red.), Aere perennius, en hommage à Hubert Zehnacker, Paris 2006, s. 125$-153$.

Evans J.D., The Art of Persuasion, Political Propaganda from Aeneas to Brutus, Ann Arbor 1992.

Franzoni C., Amphinomos e Anapias a Catania per la storia di due statue ellenistiche perdute, Kokalos 41, 1995, s. 209-227.

von Fritze H., Die Münzen von Ilion, [w:] W. Dörpfeld (red.), Troja und Ilion: Ergebnisse der Ausgrabungen in den vorhistorischen und historischen Schichten von Ilion 1870-1894, 2, Athen 1902, s. 477-534. 
Fuchs W., Die Bildgeschichte des Flucht des Aeneas, [w:] W. Haase (red.), Aufstieg und Niedergang der römischen Welt. Geschichte und Kultur Roms im Spiegel der neueren Forschung, Berlin-New York 1973, I, 4, s. 615-632.

Gaebler H., Die antiken Münzen Nord-Griechenlands, 3. Makedonia und Paionia, 2, Berlin 1935.

Gagé J., Romulus-Augustus, Mélanges de l'École française de Rome 47, 1930, s. 138-181.

Galinsky G.K., Aeneas, Sicily, and Rome, Princeton 1969.

Giampiccolo E., La Miranda Fabula dei Pii Fratres: la leggenda, le monete, la statua, Rivista di cultura classica e medioevale 52, 1, 2010, s. 71-79.

Gnecchi F., I medaglioni romani, descritti ed illustrati, Milano 1912.

Grueber H.A., Coins of the Roman Republic in the British Museum, London 1910.

Guzzetta G., La monetazione in Sicilia in „età romana”, [w:] C. Miccichè, S. Modeo, L. Santagati (red.), La Sicilia romana tra Repubblica e Alto Impero, Caltanissetta 2007, s. 185-198.

Head B.V., Historia Nummorum. A Manual of Greek Numismatics, Oxford 1887.

Horsfall N.M., The Aeneas Legend from Homer to Virgil, [w:] J.N. Bremmer, N.M. Horsfall, Roman Myth and Mythography, London 1987, s. 12-24.

Horsfall N., The Iconography of Aeneas' Flight: a Pratical Detail, Antike Kunst 22, 2, 1979, s. 104-105.

IG = Inscriptiones Graecae, Berolini 1873-2008.

Komnick H., Die Restitutionsmünzen der frühen Kaiserzeit. Aspekte der Kaiserlegitimation, Berlin-New York 2001.

Kopij K., Pietas in the Propaganda of Sextus Pompey, Studies in Ancient Art and Civilization 15, 2011, s. 203-218.

Korhonen K., Le iscrizioni del Museo Civico di Catania. Storia delle collezioni - Cultura epigrafica - Edizione, Helsinki 2004.

Krumme M., Römische Sagen der antiken Münzprägung, Marburg 1995.

Manganaro G., La monetazione di Katane dal V al I sec. a.C., [w:] B. Gentili (red.), Catania antica, Roma 1996, s. 303-321.

Mani Hurter S., Die Didrachmenprägung von Segesta mit einem Abhang der Hybriden, Teilstücke und Tetradrachmen sowie mit einem Überblick über die Bronzeprägung, Bern 2008.

Massa-Pairault F.H., Il problema degli stylopinakia del tempio di Apollonis a Cizico. Alcune considerazioni, Annali della Facoltà di Lettere e Filosofia, Università degli studi di Perugia 19, 1981-1982, s. 147-220.

Mazzarino S., I Vandali a Catania (a proposito di una nuova epigrafe catanese), Rivista del comune di Catania 4, 1954, s. 111-114.

Mielczarek M., Mennictwo starożytnej Grecji. Mennictwo okresów archaicznego i klasycznego, 1, Warszawa-Kraków 2006.

Mikocki T., Zgodna, pobożna, płodna, skromna, piękna... Propaganda cnót żeńskich w sztuce rzymskiej, Wrocław 1997.

Mirone S., Le monete coniate in Catania in memoria dei Pii Fratres, Rivista Italiana di Numismatica e Scienze Affini 29, 1916, s. 223-234.

Mirone S., Le monete dell'antica Catana, Rivista Italiana di Numismatica e Scienze Affini 31, 1918, s. 9-76.

Mommsen Th., Geschichte des römischen Münzwesens, Berlin 1860.

Monnaies Romaines Antiques (collection H.C. Levis), Genève 1925.

Morawiecki L., Władza charyzmatyczna w Rzymie u schyłku republiki (lata 44-27 r. p.n.e.), Rzeszów 1989.

Morgano F., La leggenda dei pii fratres, Archivio Storico per la Sicilia Orientale 31, 1935, s. $108-112$.

Münzer F., Herennius 46, [w:] G. Wissowa et al. (red.), Paulys Real-Encyclopädie der classischen Altertumswissenschaft 8, 1, Stuttgart 1912, szp. 679-680. 
Pera R., L'imperatore ed il divino: il simbolismo del Palladio, [w:] M. Caccamo Caltabiano, D. Castrizio, M. Puglisi (red.), La tradizione iconica come fonte storica: il ruolo della numismatica negli studi di iconografia, Reggio Calabria 2004, s. 75-91.

Perassi C., I pii fratres e il pius Aeneas problemi circa l'iconografia di monete della Sicilia e dell'età repubblicana romana, Aevum 16, 1, 1994, s. 59-87.

Perassi C., La creazione di un tipo monetale il caso di pietas sulle emissioni romane di età repubblicana, Aevum 71, 1, 1997, s. 123-149.

Petrillo Serafin P., La pietas di Enea: due monete a confronto, Bollettino d'Arte 13, 1982, s. 35-38.

Price M., Waggoner N., Archaic Greek Coinage. The Asyut Hoard, London 1975.

Roman Provincial Coinage, 1, A. Burnett, M. Amandry, P.P. Ripollès (red.), London-Paris 1992.

Santelia S., La miranda fabula dei pii fratres in Aetna 603-645, Bari 2010.

Soraci C., L'Etna e le Eolie. L'emergenza vulcane e i provvedimenti messi in atto dal governo romano, Quaderni Catanesi di Studi Antichi e Medievali 3, 2004, s. 447-474.

Sydenham E.A., The Coinage of the Roman Republic, London 1952.

Texier R., A propos de deux représentations archaïques de la fuite d’Énée, Revue Archéologique 14, 1939, s. 12-21.

Woodford S., Loudon M., Two Trojan Themes: The Iconography of Ajax Carrying the Body of Achilles and of Aeneas Carrying Anchises in Black Figure Vase Painting, American Journal of Archaeology 84, 1980, s. 25-40.

Woytek B., Arma et Nummi. Forschungen zur römischen Finanzgeschichte und Münzprägung der Jahre 49 bis 42 v. Chr., Wien 2003.

Woytek B., Die Reichsprägung des Kaisers Traianus (98-117), Wien 2010.

Zarrow E.M., Sicily and the Coinage of Octavian and Sextus Pompey: Aeneas or the Catanean Brothers?, Numismatic Chronicle 163, 2003, s. 123-135.

Zehnacker H., Moneta. Recherches sur l'organisation et l'art des émissions monétaires de la République romaine (289-31 av. J.-C.), Rome 1973. 